\title{
An Interactive Approach to Learning and Teaching in Visual Arts Education
}

Zlata TOMLJENOVić ${ }^{1}$

$\approx$ The present research focuses on modernising the approach to learning and teaching the visual arts in teaching practice, as well as examining the performance of an interactive approach to learning and teaching in visual arts classes with the use of a combination of general and specific (visual arts) teaching methods. The study uses quantitative analysis of data on the basis of results obtained from a pedagogical experiment. The subjects of the research were 285 second- and fourth-grade students from four primary schools in the city of Rijeka, Croatia. Paintings made by the students in the initial and final stage of the pedagogical experiment were evaluated. The research results confirmed the hypotheses about the positive effect of interactive approaches to learning and teaching on the following variables: (1) knowledge and understanding of visual arts terms, (2) abilities and skills in the use of art materials and techniques within the framework of planned painting tasks, and (3) creativity in solving visual arts problems. The research results can help shape an optimised model for the planning and performance of visual arts education, and provide guidelines for planning professional development and the further professional education of teachers, with the aim of establishing more efficient learning and teaching of the visual arts in primary school.

Keywords: art creativity, general and specific (visual arts) teaching methods, interactive teaching and learning, visual arts abilities and skills, visual arts knowledge, teaching strategies

1 Faculty of Teacher Education, University of Rijeka, Croatia; zlatatomljenovic@gmail.com 


\section{Interaktivni pristop k učenju in poučevanju likovne umetnosti}

ZLATA TOMLJENOVIĆ

$\propto$ Raziskava $\mathrm{v}$ prispevku se osredinja na moderniziranje pristopa učenja in poučevanja likovne umetnosti v učiteljski praksi. Poleg tega analizira izvedbo interaktivnega pristopa učenja in poučevanja likovne umetnosti z uporabo kombinacije splošnih in likovnospecifičnih metod poučevanja. Predstavljena je kvantitativna analiza podatkov, pridobljenih v pedagoškem eksperimentu. V raziskavi je sodelovalo 285 drugo- in četrtošolcev iz štirih osnovnih šol na Reki, Hrvaška. Ocenjene so bile slike, ki so jih naredili učenci na začetku in koncu eksperimenta. Rezultati potrjujejo hipoteze o pozitivnem učinku interaktivnega pristopa k učenju in poučevanju na naslednje spremenljivke: 1) poznavanje in razumevanje terminov v likovni umetnosti; 2) zmožnost in spretnost uporabe umetniških materialov in tehnik znotraj načrtovanih slikarskih nalog; 3) kreativnost pri reševanju problemov v likovni umetnosti. Rezultati lahko služijo za optimizacijo modela načrtovanja in izvajanja izobraževanja v likovnih umetnostih ter za oblikovanje smernic za načrtovanje strokovnega razvoja in nadaljnjega strokovnega izobraževanja učiteljev z namenom vzpostavitve učinkovitejšega učenja in poučevanja likovne umetnosti v osnovni šoli.

Ključne besede: kreativnost v umetnosti, splošne in likovnospecifične metode poučevanja, interaktivno poučevanje in učenje, zmožnosti in spretnosti v likovni umetnosti, znanje o likovni umetnost, poučevalne strategije 


\section{Introduction}

Rapid social change and the unpredictable future place new demands on education; schools have to teach students how to learn, think and create. Traditional education with one-way oriented communication does not satisfy contemporary needs for the integral personal development of students. The conventional approach of transmitting knowledge, where students are simply passive recipients of information, must be replaced with more effective teaching and learning based on student-centred activities and interactive, problemsolving strategies (Jagodzinski, 2009). In the visual arts teaching process, it is necessary to provide conditions for the development of the students' potential abilities to master visual arts knowledge and skills, and to acquire positive attitudes. In this process, it is necessary to encourage greater student activity, as well as emphasising the use of contemporary teaching strategies and methods, applying various styles of teaching and learning, and respecting the students' development opportunities: individual differences in adopting, understanding and interpreting the instructional content. An interactive approach to learning and teaching in visual arts education increases the interchange between all subjects in the educational process, and promotes critical and creative thinking by using active, student-centred teaching strategies such as active, experiential, independent, investigative, cooperative and problem-solving learning (Murray \& Brightman, 1996). It also leads to a better understanding of the subject matter, a better ability to synthesise and integrate learning material, increased motivation, higher order cognitive skills, greater retention of material and more positive attitudes (Smilan \& Miraglia, 2009; Van Dijk \& Jochems, 2002). Previous evaluation studies on the appropriateness of teaching the visual arts at the single-class level of primary schools point to the fact that, during the teaching process, most single-class teachers do not sufficiently apply methodical pluralism and a creative approach to learning and teaching (Tacol \& Tomšič Čerkez, 2004; Tomljenović \& Novaković, 2013). Their passive attitude is reflected in the use of established teaching methods and procedures, as well as in the lack of a greater freedom and openness to the use of more effective ways of teaching and learning. An interactive approach to learning and teaching should ensure more quality implementation of the visual arts curriculum, respecting the developmental abilities of each student according to their individual characteristics. 


\section{Features of an Interactive Approach to Learning and Teaching in Visual Arts Classes}

The main difference between traditional teaching methods and contemporary, interactive ways of teaching lies in changing one-way communication, in which the teacher has the authoritative and neutral role of knowledge transfer, to two-way communication, which takes place between all subjects in the educational process. In two-way communication, the teacher, through interaction and indirect guidance, helps the students to reach insights independently. This is why an interactive approach to teaching and learning is considered to be a social process (Šimić Šašić, 2011) that takes place through interaction between teachers and students, and between the students themselves. This approach is also considered to be more process-oriented (Van Dijk \& Jochems, 2002) and student-centred (Shreeve, Sims, \& Trowler, 2010), as teachers use various teaching strategies to involve students in cognitive and practical activities throughout the entire teaching process. The reaction of the students to the teaching activities is the most important element of the quality of teaching (Sahlberg, 2007), and the type and quality of established interaction in the classroom is directly linked to instructional outcomes (Huitt, 2003; Littlejohn \& Foss, 2007). The aim of an interactive approach to learning and teaching in visual arts education is to transfer activities from teachers to students so as to achieve more active verbal/cognitive, experiential/affective and physical/motor involvement in the teaching process.

Interaction between teachers and students in visual arts classes should include a conversation in which teachers use their visual/artistic experience to assist the students to raise their awareness of the cognitive structures that they themselves create (Burton, 2000; Matthews, 1999). According to the constructivist view of learning, students are actively involved in the construction of their mental representations and in the transformation of these representations from one form to another (Baeten, Kyndt, Struyven, \& Dochy, 2010; Louis, 2013). Students are seen as active knowledge constructors, who build their own personal knowledge based on their thinking, with the indirect help of the teacher. In this process, productive and receptive artistic activities should be implemented (Duh, Zupančič, \& Čagran, 2014). The teacher's questions should be clear and understandable to all of the students, and his/her attitude towards the students should be friendly and stimulating, so as to help them feel safe enough to express their thoughts and ideas. This is also a good way to promote positive attitudes towards the visual arts (Pavlou \& Kambouri, 2007). The teacher should ask open-ended questions that, rather than questioning knowledge, elicit the 
students' opinions on particular content, enabling the teacher to obtain information about the type and quality of the students' opinions and knowledge, and not on the quantity of memorised facts (Tomić, 2003). Depending on their individual and artistic types, students have different ways of looking at reality, i.e., they link the knowledge they possess in different ways. In the case of unusual or different responses, the teacher should show flexibility and ask the students how they came up with their ideas or what made them reach their conclusion, as the teacher can learn a lot about the way students think from their responses. This is why an effective classroom conversation is always improvisational. Teaching in the visual arts should be also a creative art, an improvisational performance (Sawyer, 2004).

The socio-emotional relationship between teachers and students is also a key component that affects the success of the teaching and the learning outcomes of the students, especially in primary school. In communication with students, it is important for teachers to give students communication feedback on the effectiveness of their performance and on their understanding of the teaching content (Kumar, 2003; Pavlou \& Kambouri, 2007).

\section{Contemporary Teaching Strategies and Methods as a Factor of Successful Interactive Teaching and Learning}

In visual arts education, teachers should use teaching strategies that enable a problem-solving approach to learning by way of examples, incentives, research questions, analogies and the use of acquired visual arts knowledge (Craft, 2001; Efland, 2002). Appropriate interaction in visual arts classes encourages brainstorming, analogical thinking, transformational thinking, visualisation, association and code-switching (Zimmerman, 2010). Effective teaching strategies used in interactive teaching and learning include problem-based learning, cooperative learning, experiential learning, active learning, investigative learning and learning through play.

A flexible, transformational and interactive approach to learning and teaching also requires a broader and more diverse approach to the use of teaching methods and their combination. Teaching methods used in visual arts classes should include a combination of general and subject-specific methods. Specific (visual arts) methods are modes arising from the specificities of the various artistic fields, their features and issues. Their use encourages students to think about the visual stimulus and arrive at unusual ways of observation, providing new insights and a deeper individual experience of visual and aesthetic components. These methods encourage the development of skills for solving 
visual arts problems or for critical and divergent thinking, as well as the ability to connect insights in order to create applicable knowledge in the field of the visual arts (Berce Golob, 1990; Karlavaris, 1991; Tacol, 2003). The use of specific (visual arts) methods includes: aesthetic communication between teachers, students and artworks; perception and understanding of visual arts phenomena and patterns, as well as their connection with everyday life; and the independent and creative use of visual arts materials. Specific teaching methods can be used in different ways: through the observation of artworks followed by an interactive discussion between the teacher and students, through creative didactic play, and through students' own artistic expression. Aesthetic communication between the teacher and students can proceed on the basis of the reception of artworks, referring to discussion of visual elements and their relationships, and of the use of art techniques. In this way, students become sensitised to the existence of artistic values and develop the ability to verbalise their experiences in the area of the visual arts. Derived from problem-based tasks, creative play in visual arts classes is a teaching strategy that brings the learning content to students in a creative, problem-solving and interesting way through experiential learning. Specific teaching methods are an inseparable part of interactive teaching in visual arts classes, as their application is not possible without interaction with the students, who become aware of the elements of the visual arts and their relationships by observing artworks and through conversation with the teacher, thus developing artistic and aesthetic sensibility. The application of specific teaching methods in visual arts classes therefore requires artistic and didactic expertise on the part of the teachers.

\section{Aims and Hypotheses}

The present study was motivated by the current situation in Croatian educational practice, where classroom teachers persist in the role of knowledge transmitters, mostly using established teaching methods (oral presentation, demonstration, conversation) in visual arts instruction (Tomljenović \& Novaković, 2013; Županić Benić, 2011). Student activity in visual arts classes is mainly limited to artistic expression, and there is an absence of teaching strategies that would activate the students throughout the learning process, taking account of their individual differences by using a range of teaching and learning styles. In 2005, an experimental programme called the Croatian National Educational Standard (Hrvatski nacionalni obrazovni standard - HNOS) was implemented in the Croatian school curriculum. It was created under the auspices of the Ministry of Science, Education and Sports as a result of changes initiated 
at all levels of the education system. HNOS sets certain guidelines related to the implementation of more student activities and the use of new forms and methods of work in order to encourage these activities, as well as the development of the students' visual arts skills as part of the full development of their personality (Vodič kroz HNOS za osnovnu školu, 2005). These concepts also imply a shift towards contemporary models of the teaching process, which encourage an interactive and problem-solving approach to learning and teaching.

The aims of the research were:

- $\quad$ to develop a model of teaching the visual arts in classrooms that will provide a greater knowledge and understanding of visual arts terms, better development of the students' abilities and skills in the use of art materials and techniques, and greater art creativity on the part of students;

- to improve student achievement in solving visual arts problems in the area of painting, using an interactive approach as well as general and specific (visual arts) teaching methods.

Within the set tasks, the aim was to create and verify an alternative optimised model of teaching that includes an interactive approach to learning and teaching with the use of general and specific teaching methods, in order to improve the quality of visual arts education.

With regard to the research aims, the following hypotheses were formed: $\mathrm{H} 1$ : Students in the experimental group will demonstrate greater knowledge and understanding of visual arts terms than students in the control group.

$\mathrm{H}_{2}$ : Students in the experimental group will demonstrate better abilities and skills in the use of art materials and techniques than students in the control group. $\mathrm{H}_{3}$ : Students in the experimental group will demonstrate greater creativity in solving painting tasks than students in the control group.

\section{Methodology}

In the study, which is based on quantitative research paradigms, we undertook a pedagogical experiment that was designed to evaluate the impact of an interactive approach to teaching and learning in visual arts education on: (1) the students' knowledge and understanding of visual arts terms, (2) the students' abilities and skills in the use of art materials and techniques within the anticipated painting tasks, and (3) the students' creativity in solving visual arts problems in the area of painting. For the purpose of testing the variables in the study, two different ways of teaching were included. The first was an interactive approach to learning and teaching, with the use of a combination of general 
and specific teaching methods, while the second was characterised by the use of common, well-established approaches to learning and teaching. The experiment was conducted in parallel groups (control and experimental groups), which were used to test the hypotheses about the success of the experimental model of teaching. A five-point Likert scale was used for the evaluation of the variables (evaluation was conducted by three independent assessors). The objectivity of the evaluation scale was determined by clear and detailed instructions for evaluating knowledge of visual arts terms, abilities and skills in the use of art techniques, and the creativity of students. The research was conducted in 2012, and the statistical analysis was undertaken using the statistical package Statistica, version 8.0, StatSoft, Inc.

\section{Sample}

The research was conducted on a sample of 285 second- and fourthgrade students from four primary schools in the city of Rijeka (Table 1).

Table 1. Number of participants and distribution of students by grade

\begin{tabular}{llccc}
\hline & Group & \multicolumn{1}{c}{} & $\mathbf{f} \%$ \\
\hline \multirow{2}{*}{$2^{\text {nd }}$} & control group & 71 & 143 & \\
& experimental group & 72 & & 50.2 \\
\hline \multirow{2}{*}{$4^{\text {th }}$} & control group & 68 & 142 & \\
& experimental group & 74 & & 49.8 \\
\hline Total & & & 285 & 100 \\
\hline
\end{tabular}

\section{Procedure}

A total of 16 classes ( 8 in the second grade and 8 in the fourth grade) were included in the pedagogical experiment. Of these, 8 classes ( 4 in the second grade and 4 in the fourth grade) represented the control group, while the other 8 classes ( 4 in second grade and 4 in the fourth grade) made up the experimental group. On selecting the sample, an effort was made to ensure that the classes had similar characteristics (material and technical conditions of work; number, gender and achievement of the students). The classes were dislocated: the sample consisted of 285 students (139 students in the control group and 146 in the experimental group) and 16 single-class teachers ( 8 teachers in the control group and 8 in the experimental group). In the second grade classes, a total of 715 student paintings were created: 360 in the experimental group and 355 in the control group. In the fourth grade classes, a total of 710 student paintings were painted: 340 in the experimental group and 370 in the control group. 
The students' paintings were created as a result of the execution of five teaching units from the area of painting, as provided by the mandatory National Curriculum for Primary School (Nastavni plan i program za osnovnu školu, 2006). The first unit was used to verify the initial state and was conducted in all of the classes, with the teachers teaching students according to their normal operating mode. The other four teaching units were undertaken within the control and experimental groups. Each teaching unit lasted 90 minutes; one advantage of the block schedule is that it allows teachers to engage students in various (inter)active teaching strategies that require more time than the traditional schedule allows (Jenkins, Queen, \& Algozzine, 2002). In order to achieve the greatest possible objectivity of the results, the control and experimental groups were given the same visual arts problem, visual arts motif and art technique within particular lessons. Teachers in the control group (hereinafter referred to as the CG) had freedom in designing lessons and worked in the usual way. Prior to teaching in the experimental group (hereinafter referred to as the EG), teachers received specially designed instructional guidelines from the research leader professional, and were provided with assistance in the form of training, consultancy and advice. In the EG, the teaching units were implemented on the basis of detailed preparation, in which special emphasis was placed on the interactive presentation of teaching materials, the use of different teaching aids and equipment, and the use and combination of various general and specific teaching methods so that all of the learning styles of the students were represented and their involvement and activity was encouraged. The teachers in the EG used a combination of general teaching methods (oral presentation, discussion, demonstration, problem-solving) and four subject-specific teaching methods (aesthetic communication, expansion and elaboration of artistic sensibility, transposition and alternatives, and individual understanding and adoption of art techniques based on one's own experience). These methods were selected as the most appropriate for use in the field of painting in the second and fourth grades. Group work was mainly used in the execution of short creative problem-based tasks, with an emphasis on communication between the students. The educational achievements in the teaching units were: the perception, visual distinction, naming, comparing, researching and expression of different colours, shapes and other artistic elements and their relationships; the acquisition of the foreseen visual arts terms; the recognition of given visual arts problems and techniques in artworks; the research of features of visual arts material and techniques; the development of visual thinking and imagination. Certain key concepts were explained to the teachers: the importance of communication with students and ways of asking questions, encouraging active conversation as 
a basis for better adoption of visual concepts, and the development of creative thinking and expression. Teachers were also made aware of the need to use various teaching aids and equipment. PPT presentations were prepared for each teaching unit, along with various reproductions of artworks, games and other teaching aids. On this basis, teachers became aware of new possibilities for the presentation of the teaching content and the organisation of the teaching process, thus modifying their instructional approach. All of the participants took part in the study voluntarily, and their anonymity was guaranteed.

The survey results are based on an assessment of the students' paintings according to the following aforementioned criteria: knowledge and understanding of visual arts terms, abilities and skills in the use of art materials, and techniques and creativity in solving visual arts problems. These criteria were set based on the main outcomes, i.e., the most important competences that students acquire in visual arts education. Knowledge and understanding of visual arts terms includes knowledge and understanding of visual language (visual and structural elements), as well as understanding the characteristics of visual concepts and their implementation in solving visual tasks. Abilities and skills in the use of art materials and techniques includes a skilled command of art materials, enabling the students to master the methods of art technique performance, and their creative use in solving visual arts problems. Creativity in solving visual arts problems includes six categories: sensitivity to problems (observation of artistic values, recognising and experiencing visual arts tasks), elaboration (organisation and use of visual elements, performance of art composition), flexibility (flexible adaption to art-expressive instruments; solving visual arts problems in a new way), fluency (richness of art ideas), originality (unusual and individual realisation of art ideas) and redefinition (connection and redefinition of previous art experiences into new artistic content/structures) (Karlavaris \& Berce Golob, 1991).

\section{Results and Discussion}

The results of the pedagogical experiment are based on a statistical analysis of the students' paintings. After the completion of the experiment, the paintings were examined and assessed by three independent assessors on the basis of a five-point Likert scale. Summary assessments were designed so that the three different grades of each assessor for each rating class and for each teaching unit were totalled and the average of the three ratings for each variable was taken as the final score for that variable. The interclass correlation coefficient (ICC) was used to determine the reliability of the instrument, based on 
which the three independent assessors evaluated the students' artwork. The results show that the coefficient value is very high $(\alpha>.80)$, which confirms the very high reliability of the evaluation scale.

\section{Comparison of the Control Group and Experimental Group in the Initial State}

The normality of the results distribution for each of the dimensions was checked using the Kolmogorov-Smirnov (KS) test. Due to abnormalities in the results distribution, the nonparametric Mann-Whitney U test was used for further statistical analysis. The Mann-Whitney $U$ test was used to evaluate differences in mean ratings between the two groups according to knowledge and understanding of visual arts terms, abilities and skills in the use of art materials and techniques, and creativity in solving visual arts problems (which comprises six variables). The two groups were compared in each dimension, both in the initial phase and after each of the four subsequent teaching units.

Table 2. Results of the Mann-Whitney $U$ test in the initial state of the control group and the experimental group

\begin{tabular}{|c|c|c|c|c|c|c|c|}
\hline & & $\begin{array}{c}\text { Mann-Whitn } \\
\text { U }\end{array}$ & $\begin{array}{c}\text { Wilcoxon } \\
\text { W }\end{array}$ & Z & $\mathrm{p}$ & $\begin{array}{c}\text { CG } \\
\text { Median }\end{array}$ & $\begin{array}{c}\text { EG } \\
\text { Median }\end{array}$ \\
\hline \multicolumn{2}{|c|}{ KNOWLEDGE } & 9698.500 & 20138.500 & -.263 & 0.793 & 2.00 & 2.00 \\
\hline \multicolumn{2}{|c|}{ USE OF ART TECHNIQUES } & 9805.000 & 20245.000 & -.106 & 0.915 & 2.00 & 2.00 \\
\hline \multirow{6}{*}{ 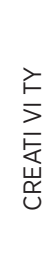 } & Sensitivity & 9270.000 & 19710.000 & -.911 & 0.362 & 2.00 & 1.67 \\
\hline & Elaboration & 9270.000 & 19710.000 & -.911 & 0.362 & 2.00 & 1.67 \\
\hline & Flexibility & 9088.000 & 18541.000 & -1.320 & 0.187 & 2.00 & 2.00 \\
\hline & Fluency & 9703.000 & 19156.000 & -.249 & 0.804 & 2.00 & 2.00 \\
\hline & Originality & 9703.000 & 19156.000 & -.249 & 0.804 & 2.00 & 2.00 \\
\hline & Redefinition & 9545.500 & 18998.500 & -.570 & 0.569 & 2.00 & 2.00 \\
\hline \multicolumn{2}{|c|}{ SUMM: INIT. T. UNIT } & 9832.000 & 20272.000 & -.047 & 0.962 & 1.88 & 1.92 \\
\hline
\end{tabular}

$N=285$

The results show that there are no statistically significant differences between the CG and the EG in the initial state (Table 2).

\section{Comparison of the Control Group and the Experimental Group in the} Final State

Data on the results of the pedagogical experiment were obtained using the same instruments as the data for the initial state. 
Table 3. Results of the Mann-Whitney U test in comparing the state in the control group and the experimental group after performing the first teaching unit

\begin{tabular}{|c|c|c|c|c|c|c|c|}
\hline & & $\begin{array}{c}\text { Mann-Whitn } \\
U\end{array}$ & $\begin{array}{l}\text { Wilcoxon } \\
\text { W }\end{array}$ & z & $\mathrm{p}$ & $\begin{array}{c}\text { CG } \\
\text { Median }\end{array}$ & $\begin{array}{c}\text { EG } \\
\text { Median }\end{array}$ \\
\hline KNO & VLEDGE & 2417.500 & 11870.500 & -11.602 & 0.000 & 2.00 & 3.00 \\
\hline USE & F ART TECHNIQUES & 2085.000 & 11538.000 & -11.955 & 0.000 & 2.00 & 3.00 \\
\hline \multirow{6}{*}{ 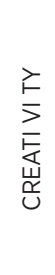 } & Sensitivity & 2494.500 & 11947.500 & -11.482 & 0.000 & 2.00 & 3.00 \\
\hline & Elaboration & 3272.000 & 12725.000 & -10.238 & 0.000 & 2.00 & 3.00 \\
\hline & Flexibility & 2986.500 & 12439.500 & -10.927 & 0.000 & 2.00 & 3.00 \\
\hline & Fluency & 3506.000 & 12959.000 & -10.115 & 0.000 & 2.00 & 3.00 \\
\hline & Originality & 3000.000 & 12453.000 & -11.182 & 0.000 & 2.00 & 3.00 \\
\hline & Redefinition & 2569.500 & 12022.500 & -11.735 & 0.000 & 2.00 & 3.00 \\
\hline \multicolumn{2}{|c|}{ SUMM: T. UNIT 1} & 1614.000 & 11067.000 & -12.150 & 0.000 & 2.00 & 3.00 \\
\hline
\end{tabular}

Table 4. Results of the Mann-Whitney U test in comparing the state in the control group and the experimental group after performing the second teaching unit

\begin{tabular}{|c|c|c|c|c|c|c|c|}
\hline & & $\begin{array}{c}\text { Mann-Whitn } \\
U\end{array}$ & $\begin{array}{l}\text { Wilcoxon } \\
\text { W }\end{array}$ & Z & $\mathrm{p}$ & $\begin{array}{c}\text { CG } \\
\text { Median }\end{array}$ & $\begin{array}{c}\text { EG } \\
\text { Median }\end{array}$ \\
\hline \multicolumn{2}{|c|}{ KNOWLEDGE } & 2400.500 & 11853.500 & -11.550 & 0.000 & 2.00 & 3.00 \\
\hline \multicolumn{2}{|c|}{ USE OF ART TECHNIQUES } & 1511.500 & 10964.500 & -12.940 & 0.000 & 2.00 & 3.00 \\
\hline \multirow{6}{*}{ 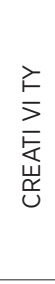 } & Sensitivity & 1996.500 & 11449.500 & -12.013 & 0.000 & 2.00 & 3.00 \\
\hline & Elaboration & 2169.000 & 11622.000 & -11.948 & 0.000 & 2.00 & 3.00 \\
\hline & Flexibility & 2537.500 & 11990.500 & -11.601 & 0.000 & 2.00 & 3.00 \\
\hline & Fluency & 2576.500 & 12029.500 & -11.508 & 0.000 & 2.00 & 3.00 \\
\hline & Originality & 2360.000 & 11813.000 & -12.208 & 0.000 & 2.00 & 3.00 \\
\hline & Redefinition & 2132.500 & 11585.500 & -12.444 & 0.000 & 2.00 & 3.00 \\
\hline \multicolumn{2}{|c|}{ SUMM: T. UNIT 2} & 1368.500 & 10821.500 & -12.536 & 0.000 & 2.00 & 3.00 \\
\hline
\end{tabular}

$N=285$ 
Table 5. Results of the Mann-Whitney U test in comparing the state in the control group and the experimental group after performing the third teaching unit

\begin{tabular}{|c|c|c|c|c|c|c|c|}
\hline & & $\begin{array}{c}\text { Mann-Whitn } \\
U\end{array}$ & $\begin{array}{l}\text { Wilcoxon } \\
\text { W }\end{array}$ & z & $\mathrm{p}$ & $\begin{array}{c}\text { CG } \\
\text { Median }\end{array}$ & $\begin{array}{c}\text { EG } \\
\text { Median }\end{array}$ \\
\hline \multicolumn{2}{|c|}{ KNOWLEDGE } & 1480.500 & 10933.500 & -12.986 & 0.000 & 2.00 & 4.00 \\
\hline \multicolumn{2}{|c|}{ USE OF ART TECHNIQUES } & 1187.500 & 10640.500 & -13.385 & 0.000 & 2.00 & 3.00 \\
\hline \multirow{6}{*}{ 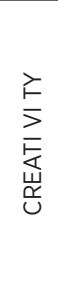 } & Sensitivity & 1121.500 & 10574.500 & -13.392 & 0.000 & 2.00 & 3.00 \\
\hline & Elaboration & 1723.500 & 11176.500 & -12.462 & 0.000 & 2.00 & 3.00 \\
\hline & Flexibility & 1688.500 & 11141.500 & -12.827 & 0.000 & 2.00 & 3.00 \\
\hline & Fluency & 1690.000 & 11143.000 & -12.825 & 0.000 & 2.00 & 3.00 \\
\hline & Originality & 1580.000 & 11033.000 & -13.253 & 0.000 & 2.00 & 3.00 \\
\hline & Redefinition & 1455.500 & 10908.500 & -13.375 & 0.000 & 2.00 & 3.00 \\
\hline \multicolumn{2}{|c|}{ SUMM: T. UNIT 3} & 792.000 & 10245.000 & -13.396 & 0.000 & 2.00 & 3.25 \\
\hline
\end{tabular}

Table 6. Results of the Mann-Whitney U test in comparing the state in the control group and the experimental group after performing the fourth teaching unit

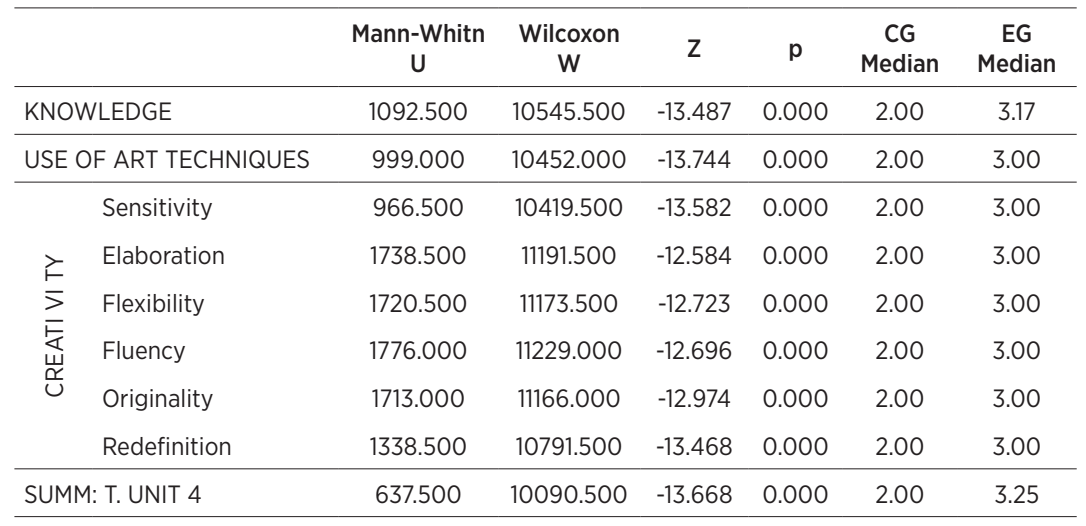

$N=285$

The results given in Tables 3, 4, 5 and 6 show that there are statistically significant differences between the CG and the EG after performing teaching units 1, 2, 3 and 4 for all of the measured variables. Better results were achieved in the EG and weaker results were achieved in the CG. The results indicate that the use of the optimised interactive model of teaching employing specific (visual arts) methods in the experimental group significantly affected the improvement of the quality of teaching and the results in all areas of research 
(knowledge and understanding of visual arts terms, the use of art materials and techniques, and creativity).

With regard to knowledge and understanding of visual arts terms, it was determined that the students in the EG were more successful in solving visual arts problems than the students in the CG. The acquired knowledge of art terms was applied in a more consistent way in the EG than in the CG. In the paintings produced, this is evident in the understanding and elaboration of visual problems, in the knowledge of the main characteristics and the method of use of art materials and techniques, and in the linking of new visual arts knowledge with knowledge already acquired. It is important that the students' activity provokes their cognitive engagement through information processing in an nonautomatic and non-passive manner, at a deeper level and with more productive knowledge than in traditional learning. Studies show that the results in the field of motivation, memory and the ability to distinguish what is important from what is not are significantly higher while performing interactive teaching than the results obtained in tradition-oriented teaching (Suzić, 2002). An interactive approach to learning and teaching in visual arts classes aids the acquisition of a better understanding of visual arts terms and concepts through activities such as art appreciation and the analysis of artworks, activities that demand a process of constructing meaning (Prater, 2001).

Differences between the student artworks in the CG and the EG are also evident in the use of art materials and techniques. The students in the CG mainly used painting supplies in a common way, with no experimentation with and use of the diverse possibilities of combining art materials and techniques, despite the fact that paint is a material that offers children a wide range of representational options, as well as special features and many opportunities for expressing ideas (Louis, 2013). Students were generally more focused on the presentation of visual motifs, and less on the use of art techniques. In the EG, more attention was focused on the appropriate use of art materials. Moreover, the students were encouraged to further experimentation with painting materials and techniques and with their combinations. Consequently, the students in the EG used visual art techniques with greater sureness and increased creative exploration of their expressive possibilities. As well as providing students with various materials that allow them to express their ideas and creativity (Batič, 2014; Tomšič Čerkez, 2004), it is also important to show them how to use the art materials (in terms of the technique and technology of the materials), and then encourage them to combine the materials in various ways, exploring all of the possibilities of combining art techniques.

The student paintings in the EG also demonstrate greater creativity than 
those in the CG. They show better visual perception and a sense of artistic and aesthetic values, greater sensitivity and understanding of visual problems and different approaches in the search for new artistic solutions. In the work from the EG, the greater visual sensitivity of the majority of the students is evident in the original presentation of motifs, in the numerous visual details, in the richness of the creative ideas, and in the interesting ways of using art techniques. When solving problems, the students in the EG produced a large number of artistic ideas, demonstrated the ability to interpret the motifs in their own way, and showed inspiration and desire for experimentation, all of which resulted in original artistic solutions. Reflection on visual problems and the increased involvement of the students during their work is evident in most of the paintings. Some studies have already shown that, based on models developed in visual arts education, creativity can be enhanced and teaching strategies can be developed to stimulate creativity. In visual arts education, creativity should be viewed not as an exclusive talent or the product of extraordinary genius, but as something inherent in all students as abilities that enable one to be creative (Weisberg, 1993; Zimmerman, 2010). Therefore, creativity can be viewed as a complex process, an interactive system in which relationships between persons, processes, products, and social and cultural contexts are of paramount importance (Zimmerman, 2009). In developing creativity, interactions between teachers and students are of crucial importance (Lowenfeld, 1957). In fact, social-based instruction can be viewed as "one of these ordinary processes implicated in developing creative dispositions" (Anderson \& Yates, 1999, p. 468).

The students in the EG were encouraged to ask questions, to "think aloud" and to interact informally in smaller groups during short creative problem-solving tasks (solving visual arts problems in the form of short creative learning games) before engaging in artistic expression. Kumar (2003) argues that dividing instruction into segments characterised by various short student activities is a successful way to keep students interested and involved. Studies also show that student-centred collaborative learning promotes creative thinking in solving art and design problems, helping individuals to integrate multiple perspectives on a problem (Pun, 2012).

The use of a combination of general and specific methods also contributed to better results in the EG. The value of the effective use of general and specific teaching methods in visual arts classes has been argued by some authors (Berce Golob, 1990; Karlavaris, 1991; Tacol, 2003). The choice of specific teaching methods was made with the assumption that their focus on the specifics of visual areas justifies their use in contemporary, interactive and problem-based visual arts education. 
The use of PowerPoint presentations proved very helpful and motivating for the students in the EG. Apperson, Laws and Scepansky (2008) demonstrated that students prefer PowerPoint presentations and respond favourably to classes when they are used. PowerPoint presentations should reflect the educational purpose of the visual arts instruction and can be a powerful teaching tool when used as a stimulus for the development of perception and visual reasoning skills, for analysis of artworks, for discussion and interaction, for creating associations based on images viewed, and for developing creative exploration and expression of thought (Black \& Browning, 2011).

Based on the results, it can be concluded that the effect of the pedagogical experiment conducted is positive. The role of the teachers in the EG should also be highlighted. These teachers changed their way of teaching, showed greater commitment and proved to be a key factor in the efficient performance of the experimental model. This is even more important due to the fact that using specific active instructional methods during instruction will mostly depend on the attitudes, skills and preferences of the teachers (Van Dijk, Van Den Berg, \& Van Keulen, 1999). Teachers also play a significant role in the creative performance of their students (Baeten, Kyndt, Struyven, \& Dochy, 2010). Teachers in the EG engaged the students in learning activities such as conversation, creative didactic play, cooperative work in small groups and evaluating the results of work, which resulted in the achievement of better educational outcomes in the EG than the CG.

In view of the results obtained with the pedagogical experiment, we can conclude the following:

- Analysis of the results showed that in the final state there is a statistically significant difference between the EG and the CG in the area of knowledge and understanding of visual arts terms. Hypothesis $\mathrm{H1}$ is therefore confirmed.

- Analysis of the results also showed that in the final state there are statistically significant differences between the EG and the CG in the area of abilities and skills in the use of art materials and techniques. Hypothesis H2 is therefore confirmed.

- Analysis of the results also showed that in the final state there are statistically significant differences between the EG and the CG in all of the variables in the area of art creativity (sensitivity to visual arts problems, elaboration, flexibility, fluency, originality, redefinition). Hypothesis $\mathrm{H3}$ is therefore confirmed. 


\section{Conclusion}

The purpose of the study was to examine the effects of interactive teaching and learning in the context of visual arts education in primary school on the quality of instruction. Despite numerous studies on the results of the application of interactive learning in various educational contexts, there is no empirical research examining the effects of an interactive approach to learning and teaching in visual arts education. An interactive approach to teaching and learning in visual arts education places emphasis on better communication between all of the subjects in the educational process, as well as on the use of teaching strategies that ensure greater activity and motivation of the students, such as problem-solving learning, cooperative learning, learning through play, active learning and experiential learning. Such an approach enables students a better understanding of the teaching content and better results in artistic expression. In order to comply with the specifics of visual arts education, it is also necessary to use specific (visual arts) methods in the teaching process. The results of the study show that there are significant differences between the traditional and the interactive model of teaching and learning in visual arts education. Interactive, problem-based teaching of the visual arts, with a focus on the acquisition and understanding of visual concepts and content through students' active approach to learning, creative play, affective experience and motor activity, resulted in better instructional outcomes. After using an interactive, optimised model of teaching in the experimental group, the students' knowledge and understanding of visual arts terms, their abilities and skills in the use of art materials and techniques, and their creativity in solving art tasks increased compared to the control group. Teachers nonetheless still avoid interactive instruction in classrooms, probably due to fear of losing control over the teaching process, as well as to more demanding preparation for instruction or perhaps to inexperience (Auster \& Wylie, 2006; Van Dijk \& Jochems, 2002). These problems can be solved by organising adequate courses, discussion groups and workshops as part of the professional development of teachers.

The research results also open up opportunities for further research, which could easily be carried out in several directions. It would be interesting to research the effects of the experimental interactive model of teaching on other areas of the visual arts (drawing, sculpture, graphics), as well as on other levels of primary school teaching (younger and older age groups of students). In addition to the four specific methods used in the research, the effectiveness of other specific methods and their combinations should be analysed with regard to various visual arts problems and students of different ages. The research 
was conducted with the aim of establishing guidelines for the modernisation of the methodical process of visual arts education in primary school teaching. The research results can serve as a starting point for further studies and for the use of the specific methods in educational practice, which can be applied when revising or designing visual arts educational curricula. Through the application of an interactive approach to learning and teaching in visual arts classes, students will be able to acquire better visual arts knowledge and skills, i.e., the learning objectives prescribed by the curriculum, such as cognitive, psycho-motor and emotional development, as well as the development of aesthetic sensitivity. We assume that the results of the research will raise teachers' awareness of the need to change their approach to learning and teaching of the visual arts in the direction of a contemporary, interactive approach. In this way, visual arts classes can be conducted in a dynamic, active, competent manner, and with less routine in the classroom.

\section{References}

Anderson, A., \& Yates, G. C. (1999). Clay Modelling and Social Modelling: effects of interactive teaching on young children's creative artmaking. Educational Psychology, 19(4), 463-469.

Apperson, J. M., Laws, E. L., \& Scepansky, J. A. (2008). An assessment of student preferences for PowerPoint presentation structure in undergraduate courses. Computers \& Education, 50(1), 148-153. Auster, E. R., \& Wylie, K. K. (2006). Creating active learning in the classroom: A systematic approach. Journal of Management Education, 30(2), 333-353.

Baeten, M., Kyndt, E., Struyven, K., \& Dochy, F. (2010). Using student-centred learning environments to stimulate deep approaches to learning: Factors encouraging or discouraging their effectiveness.

Educational Research Review, 5(3), 243-260.

Batič, J. (2014). Implementing Change in Architectural Design in Elementary School Art Education in Slovenia. International Journal of Art \& Design Education, 33(1), 130-140.

Berce Golob, H. (1990). Metode likovno - vzgojnega dela v osnovni šoli na področju slikarstva.

Doctoral dissertation. Ljubljana: Akademija za likovno umetnost in oblikovanje.

Black, J., \& Browning, K. (2011). Creativity in Digital Art Education Teaching Practices. Art

Education, 64(5), 19-34.

Burton, J. M. (2000). The configuration of meaning: Learner-centered art education revisited. Studies in Art Education, 41(4), 330-345.

Craft, A. (2001). Creativity in Education. London: Continuum.

Duh, M., Zupančič, T., \& Čagran, B. (2014). Development of Art Appreciation in 11-14 year-old Students. International Journal of Art \& Design Education, 33(2), 208-222.

Efland, A. D. (2002). Art and Cognition: Integrating the Visual Arts in the Curriculum. New York/ Reston: Teachers College Press, Columbia University and National Art Education Association. 
Huitt, W. (2003). A transactional model of the teaching/learning process. Educational Psychology Interactive. Retrieved 03.10.2012 from http://www.edpsycinteractive.org/materials/tchlrnmd.html Jagodzinski, J. (2009). Beyond aesthetics: Returning force and truth to art and its education. Studies in Art Education, 50(4), 338-351.

Jenkins, E., Queen, A., \& Algozzine, B. (2002). To block or not to block: That's not the question. The Journal of Educational Research, 95(4), 196-202.

Karlavaris, B. (1991). Metodika likovnog odgoja 1. Rijeka: Hofbauer p.o.

Karlavaris, B., \& Berce Golob, H. (1991). Likovna vzgoja: priročnik za učitelje razrednega pouka. Ljubljana: DSZ.

Kumar, S. (2003). An innovative method to enhance interaction during lecture sessions. Advances in physiology education, $27(1), 20-25$.

Littlejohn, S. W., \& Foss, K. A. (2007) Theories of Human Communication. Belmont, CA: Thomson Learning Inc.

Louis, L. (2013). "No one's the boss of my painting:” A model of the early development of artistic graphic representation. International Journal of Education \& the Arts, 14(11). Retrieved 10.12.2014 from http://www.ijea.org/v14n11/

Lowenfeld, V. (1957). Creative and mental growth. ( $3^{\text {rd }}$ ed.). New York: Mcmillan.

Matthews, J. (1999). The Art of Childhood and Adolescence: The Construction of Meaning. London: Falmer Press.

Murray, R., \& Brightman, J. R. (1996). Interactive teaching. European journal of engineering education, 21(3), 295-308.

Nastavni plan i program za osnovnu školu (2010). Zagreb: Ministarstvo znanosti, obrazovanja i športa Republike Hrvatske.

Pavlou, V., \& Kambouri, M. (2007). Pupils' attitudes towards art teaching in primary school: an evaluation tool. Studies in Educational Evaluation, 33(3), 282-301.

Prater, M. (2001). Constructivism and technology in art education. Art Education, 54(6), 43-48. Pun, S. K. (2012). Collaborative Learning: a means to Creative Thinking in Design. International Journal of Education and Information Technologies, 6(1), 33-43.

Sahlberg, P. (2007). Education policies for raising student learning. The Finnish approach. Journal of Education Policy, 22(2), 147-171.

Sawyer, R. K. (2004). Creative teaching: Collaborative discussion as disciplined improvisation. Educational researcher, 33(2), 12-20.

Shreeve, A., Sims, E., \& Trowler, P. (2010). 'A kind of exchange': learning from art and design teaching. Higher Education Research \& Development, 29(2), 125-138.

Smilan, C., \& Miraglia, K. M. (2009). Authentic Art Integration. Art Education, 62(6), 39-45.

Suzić, N. (2002). Efikasnost interaktivnog učenja u nastavi: eksperimentalna provjera. Obrazovna tehnologija, 2, 13-45.

Šimić Šašić, S. (2011). Interakcija nastavnik-učenik: teorije i mjerenje. Psihologijske teme, 20(2), 233260. 
Tacol, T. (2003). Likovno izražanje: didaktična izhodišča za problemski pouk likovne vzgoje v devetletni osnovni šoli. Ljubljana: Debora.

Tacol, T., \& Tomšič-Čerkez, B. (2004). Poučevanje likovne vzgoje v novem kurikulu. In Učitelj med zahtevami, možnostmi in pričakovanji, zbornik radova, Hotel Kompas, Kranjska Gora, 11-13 March 2004. Ljubljana: Zveza društev pedagoških delavcev Slovenije.

Tomić, A. (2003). Izbrana poglavja iz didaktike. Ljubljana: Filozofska fakulteta, Center za pedagoško izobraževanje.

Tomšič Čerkez, B. (2004) Likovni materiali in tridimenzionalne predstavitve prostora [Art materials and three-dimensional presentations of space]. Likovna vzgoja, 5/6(27-8), 25-37.

Tomljenović, Z., \& Novaković, S. (2013). Mišljenja učitelja razredne nastave o učenju i poučavanju likovne kulture u osnovnoj školi [Classroom teachers' opinions on learning and teaching of visual arts in elementary school]. Inovacije $u$ nastavi, $27(1), 31-41$.

Van Dijk, L. A., \& Jochems, W. M. G. (2002). Changing a traditional lecturing approach into an interactive approach: Effects of interrupting the monologue in lectures. International Journal of engineering education, 18(3), 275-284.

Van Dijk, L. A., van den Berg, G. C., \& van Keulen, H. (1999). Using active instructional methods in lectures: a matter of skills and preferences. Innovations in education and training international, $36(4)$, 260-272.

Vodič kroz Hrvatski Nacionalni Obrazovni Standard za osnovnu školu (2005). Zagreb: Ministarstvo znanosti, obrazovanja i športa Republike Hrvatske.

Weisberg, R. W. (1993). Creativity: Beyond the myth of genius. New York: Freeman.

Zimmerman, E. (2009). Reconceptualizing the role of creativity in art education theory and practice.

Studies in Art Education, 50(4), 382-399.

Zimmerman, E. (2010). 2010 Lowenfeld Lecture Creativity and Art Education: A Personal Journey in Four Acts. Art Education, 63(5), 84-94.

Županić Benić, M. (2011). Uloga učitelja u komunikaciji djeteta s likovnim djelom. In A. Balić-

Šimrak (Ed.), Umjetničko djelo u likovnom odgoju i obrazovanju (pp. 144-157). Zbornik umjetničkoznanstvenih skupova 2009-2011. Zagreb: ECNSI Zagreb, Učiteljski fakultet Sveučilišta u Zagrebu.

\section{Biographical note}

Zlata Tomljenović is a postdoc of Theory of Visual Arts, at the Faculty of Teacher Education, University of Rijeka, Croatia. She was born on 12 October 1969. In 1994 she graduated from the Faculty of Education in Rijeka Department of Art Education. In 2006 she obtained her Master's degree in the area of restoration and conservation at the Academy of Fine Arts and Design in Ljubljana, Slovenia. In 2009 she enrolled into the Faculty of Education, University of Ljubljana, into the doctoral study programme The Education of Teachers 
and Educational Sciences, Teaching in the area of art. In 2014 she defensed her dissertation and earned a $\mathrm{PhD}$ degree. Since 2008 she has been employed at the Faculty of Teacher Education, University of Rijeka. She has actively participated in international and national scientific conferences and she is the author of nine scientific papers. Her main research topics concern student teachers' and teachers' general and subject-specific (visual arts) competences, teachers' professional development, interactive learning and teaching, teaching and learning strategies and methods in the context of visual arts education. 